\title{
Pengaturan Sanksi Tentang Perubahan Anggaran Dasar Perseroan Terbatas Tanpa Persetujuan Kemenkumham
}

\author{
Ade Chrisna Wardana Putra ${ }^{1}$
}

1Program Studi Magister Kenotariatan,Fakultas Hukum Universitas Udayana ,

E-mail: adechrisna94@gmail.com

\begin{tabular}{l} 
Info Artikel \\
\hline Masuk: 1 Agustus 2020 \\
Diterima : 5 Agustus 2020 \\
Terbit : 28 Agustus 2020 \\
Keywords : \\
Legal protection; Traditional \\
Knowledge; Copyrights \\
\\
Kata kunci: \\
Sanksi, Perseroan \\
Terbatas,Perubahan Anggaran \\
Dasar \\
Corresponding Author: \\
Ade Chrisna Wardana Putra,
\end{tabular}

\begin{abstract}
Research on Sanction Arrangements Regarding Changes to the Articles of Association of Limited Liability Companies Without the Approval of the Ministry of Law and Human Rights. Pursuant to the non-regulation of limited liability companies that violate the provisions of Article 21 paragraph (1) of Law Number 40 Year 2007 concerning Limited Liability Companies regarding obtaining approval from the Ministry of Law and Human Rights in changes to the articles of association concerning changes in company names and company goals, but still uses the deed to amend the articles of association new. Based on the norms, the following problem formulations are formulated: (1) How are sanctions on Limited Liability Companies using the new Articles of Association Amendment Deed but not yet approved by the Ministry of Law and Human Rights? (2) What is the position of the Deed of Amendment to the Articles of Association of a Limited Liability Company that has not yet been approved by the Ministry of Law and Human Rights? The aim is to understand how important the approval of the Ministry of Law and Human Rights to the Amendment to the Articles of Association of a Limited Liability Company for a Limited Liability Company and the sanction of disapproval of the Deed of Amendment to the Limited Liability Company by the Ministry of Law and Human Rights. This research is categorized as a normative legal research. The approach used in this research is the conceptual approach and legislation. The results of the study show that if sanctions on Limited Liability Companies violating the use of amendments to the articles of association which have not been approved by the Ministry of Law and Human Rights are subject to sanctions regulated in article 1365 of the Civil Code and article 378 of the Criminal Code. The status of the deed of amendment to the articles of association which the new Limited Liability Company has not obtained the approval of the Ministry of Law and Human Rights cannot bind the parties and the Limited Liability Company can only use the deed of amendment to the old budget.

\begin{tabular}{l} 
Abstrak \\
\hline Penelitian tentang Pengaturan Sanksi Terhadap Perubahan \\
Anggaran Dasar Perseroan Terbatas Tanpa" Persetujuan \\
Kemenkumham. Berdasarkan tidak diaturnya sanksi terhadap \\
PT yang melanggar ketentuan Pasal 21 ayat (1) Undang- \\
Undang Nomor 40 Tahun 2007 Tentang Perseroan Terbatas \\
mengenai hal mendapatkan persetujuan Kemenkumham dalam \\
perubahan anggaran dasar menyangkut perubahan nama
\end{tabular}
\end{abstract}




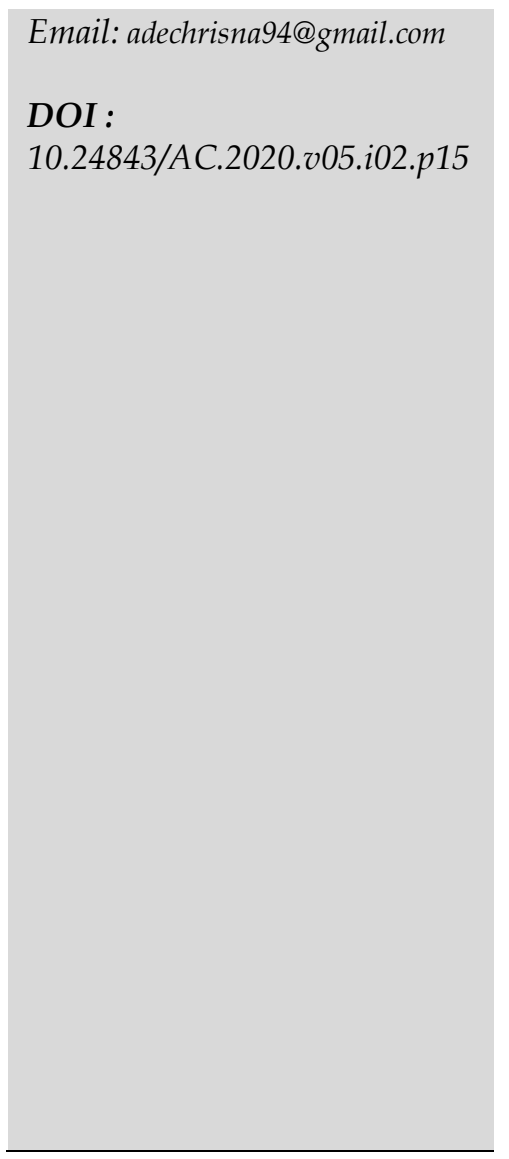

\begin{abstract}
perusahaan serta tujuan perusahaan namun tetap menggunakan akta perubahan anggaran dasar yang baru. Berdasarkan kekosongan norma kemudian diangkatlah topik permasalahan yang akan dibahas yakni: (1) Bagaimana sanksi terhadap Perseroan Terbatas yang menggunakan Akta Perubahan Anggaran Dasar yang baru namun belum disetujui oleh Kemenkumham? (2) Bagaimana kedudukan Akta Perubahan Anggaran Dasar PT yang belum mendapatkan persetujuan Kemenkumham? Tujuanya adalah untuk memahami betapa penting persetujuan Kemenkumham terhadap Perubahan Akta Anggaran Dasar PT bagi usaha PT serta pemberian sanksi dari tidak disetujuinya Akta Perubahan Anggaran Dasar Perseroan Terbatas oleh Kemenkumham sehingga memiliki manfaat langsung untuk pembaca yang memiliki keinginan untuk mendirikan PT. Penelitian ini dikategorikan sebagai penelitian hukum yang bersifat normatif. Pendekatan yang digunakan pada penelitan ini adalah pendekatan perundang-undangan dan pendekatan konseptual.Hasil penelitian menunjukan jika sanksi terhadap Perseroan Terbatas yang melakukan pelanggaran menggunakan akta perubahan anggaran dasar yang belum disahkan oleh Kemenkumham dikenakan sanksi yang diatur dalam pasal 1365 KUHPerdata dan pasal 378 KUHPidana. Kedudukan akta perubahan anggaran dasar yang PT baru kemudian belum mendapatkan persetujuan Kemenkumham itu tidak dapat mengikat para pihak dan PT hanya dapat menggunakan akta perubahan anggaran yang lama.
\end{abstract}

\title{
I. Pendahuluan
}

Perseroan terbatas (selanjutnya disebut PT) sangat memiliki peran penting dalam membangun perkembangan perekonomian Negara kita yaitu Republik Indonesia. ${ }^{1}$ Perseroan Terbatas menjadi penggerak kehidupan masyarakat modern, karenanya kehidupan masyarakat menjadi lebih sejahtera dalam pemenuhan kebutuhan pokoknya. Untuk Negara, adanya PT sangat membantu sebagai sarana untuk menyediakan lapangan perkerjaan untuk berbagai kalangan dan lapisan masyarakat di Indonesia. PT juga dianggap sebagai sumber pendapatan Negara dari sektor pajak. PT adalah badan usaha yang keberadaanya cukup banyak diminati di Indonesia. Jumlahnya bahkan bisa melebihi jumlah jenis perusahaan-perusahaan lainya yaitu seperti Firma, CV, Koperasi, UD, dan lain-lain. Istilah Perseroan Terbatas terbentuk atas 2 suku kata diantaranya kata perseoran dan juga terbatas. Perseroan lebih mengacu kepada harta kekayaan yang dimiliki oleh PT. Terbatas disini dimaksudkan lebih merujuk dengan bagaimana pemilik saham itu dapat bertanggung jawab sesuai pada nilai jumlah sahamnya. ${ }^{2}$ PT termasuk dalam suatu badan usaha yang memiliki kekuatan hukum dan terbentuk melalui sebuah kesepakatan antara

1 Pahlefi. (2016). Eksitensi RUPS sebagai Organ Perseroan Terkait Dengan Pasal 91 Undang-Undang Perseroan Terbatas.Jurnal Ilmu Hukum Unja, Volume 7 Nomor 2.h.126

2 Ridwan Khairandy. (2013). Karakter Hukum Perusahaan Perseroan Dan Status Hukum Kekayaan Yang Dimilikinya. Jurnal Hukum Ius Quia Iustum.h.87 
para pihak yang kemudian mereka yakni para pihak sepakat untuk bersamasama melaksanakan suatu usaha dan nilai modal nya diubah ke dalam bentuk saham sesuai ketentuan yang sudah diatur pada Undang-Undang Nomor 40 Tahun 2007 Tentang Perseroan Terbatas (selanjutnya disingkat UUPT). ${ }^{3}$ Pendirian suatu PT wajib mengikuti persyaratan dan kriteria yang sudah ditetapkan diantaranya : a.dalam mendirikan PT terdiri dari minimal 2 orang, b.pendirianya berbentuk akta notariil, c. akta pendirianya harus berbahasa indonesia, d. bagian sahamnya dapat dimiliki oleh pendiri, e. mendapatkan pengakuan sebagai badan usaha berkekuatan hukum yang sah. ${ }^{4}$ Ciri-ciri Perseroan Terbatas yaitu a. mempunyai harta kekayaan sendiri dan terpisah dari orang-orang yang menjalankan kegiatan badan hukum itu, b. mempunyai hak dan kewajiban yang terpisah dari orang-orang yang menjalankan kegiatan badan hukum itu, c. mempunyai tujuan tertentu, d. Keberadaanya memiliki kesinambungan . Seiring berkembangnya sebuah bisnis pada Perseroan Terbatas yang berjalan dengan baik biasanya memerlukan penyesuaian dan perubahan. Dimulai dari perubahan pemegang saham, adanya penambahan modal, dan juga perpindahan alamat kantor perusahaan yang harus pindah dikarenakan tidak mampu menampung kapasitas karyawan yang semakin banyak. Apabila telah mendirikan Perseroan Terbatas untuk bisnis yang dijalankan, maka jika terdapat perubahan yang ada kaitanya dengan informasi perusahan/identitas perusahaan, baik apapun bentuknya, harus mengindahkan atau mematuhi peraturan terkait. Pada masalah ini informasi dalam hal ini yang ditulis pada anggaran dasar perusahaan. Jika informasi tersebut terdapat perubahan artinya harus melakukan perubahan angggaran dasar juga. Perubahan informasi/identitas sebuah Perseroan Terbatas tidak dapat dilakukan oleh sepihak dikarenakan membutuhkan peran pejabat yang berwenang yaitu notaris dan Menteri terkait. Menteri yang dimaksudkan adalah Kementrian Hukum dan HAM ( selanjutnya disingkat Kemenkumham). Perubahan tersebut mutlak dan diharuskan berbentuk akta notariil. Perubahan anggaran dasar juga melibatakan peran seorang direksi. Seorang direksi mempunyai kewajiban serta tanggung jawab untuk menjalankan tugasnya yang berkaitan dengan urusan Perseroan seperti Rapat Umum Pemegang Saham(selanjutnya disingkat RUPS). ${ }^{5}$ RUPS biasanya dilakukan sebagai prosedur jika PT ingin melakukan perubahan anggaran dasar PT. RUPS harus mendapatkan persetujuan dari 2/3 total saham dari hak suara yang hadir. Apabila tidak memenuhi syarat kuorom maka akan diadakan RUPS kembali harus dihadiri minimal 3/5 jumlah pemilik saham yang mempunyai hak untuk bersuara. Jika RUPS sudah dilakukan, mendapatkan persetujuan, dan sudah memenuhi syarat kuorum, maka setelah disetujui lalu

${ }^{3}$ H. Zainal Asikin. (2016). Pengantar Hukum Perusahaan, Jakarta:Kencana.h.51

4 Orinton Purba. (2011).Petunjuk Praktis Bagi Rups Komisaris dan Direksi Perseroan Terbatas agar Terhindar Dari Jerat Hukum, Jakarta: Raih Asa Sukses.h.22

5 Andri Wihanjaya. (2016). Analisis Terhadap Kewajiban Direksi Perseroan Dalam Menyelenggarakan Rapat Umum Pemegang Saham . Jurnal Online Mahasiswa Bidang Hukum.h.1 
akan dicantumkan pada Berita RUPS. Kemudian notaris membuatnya dalam bentuk Akta Perubahaan Anggaran Dasar. Apabila saat diadakanya RUPS sulit secara langsung untuk diadakan karena satu/lebih pemilik saham sedang keluar daerah, kemudian ada solusi lain agar dapat merubah anggaran dasar yaitu dengan melakukan penerbitan sirkuler. Penerbitan sirkuler dimungkinkan dilakukan dan jika tidak terdapat di dalam berita rapat . Para pemilik saham dalam PT wajib menandatangani sirkuler. Sirkuler tersebut yang nantinya menjadi Akta Perubahan Anggaran Dasar yang dibuat oleh notaris.

Pengaturan mengenai perubahan akta anggaran dasar PT terdapat pada Pasal 21 ayat (1) UUPT menyebutkan bahwa, perubahan hal-hal tertentu pada anggaran dasar diharuskan mendapat persetujuan dari Menteri. Hal-hal tertentu tersebut sebagaimana diatur Pasal 21 ayat (2) UUPT diantaranya:

a. nama serta lokasi berdirinyan PT

b. bidang usaha yang digeluti oleh PT,

c. tenggang waktu berdirinya PT,

d. jumlah modal yang dimiliki oleh PT,

e. pengaturan modal disetor/ ditempatkan,

f. status kedudukan dari PT bersifat tertutup hingga menjadi PT yang terbuka.

Perubahan ketentuan lain pada anggaran dasar selain yang tercantum pada Pasal 21 ayat (2) UUPT hanya disampaikan kepada Kemenkumham. Perubahan terhadap anggaran dasar harus dibuat secara notarial dan menggunakan Bahasa Indonesia. Ketentuan Pasal 21 ayat (1) UUPT memberi penekanan mengenai perubahan akta anggaran dasar wajib disetujui oleh Kemenkumham. Apabila ketika dilakukan RUPS yang menyetujui tentang perubahan anggaran dasar tidak dibuatkan Akta Berita Acara Rapat oleh notaris maka maksimal 30 (tiga puluh) hari setelah diputuskannya RUPS, harus dibuatkan akta notariil tentang pengubahan anggaran dasar tersebut. Setelah tenggang waktu 30 hari tersebut telah terlampaui maka perubahan anggaran dasar yang telah disetujui pada RUPS tidak boleh dituangkan dalam akta notaris, dengan kata lain keputusan RUPS tersebut sudah kedaluarsa. Pengajuan permohonan kepada Menteri agar menyetujui perubahan anggaran dasar dilakukan maksimal 30 (tiga puluh) hari dari tanggal akta yang dirubah dan dibuat notaris. Apabila batas waktu 30 hari tersebut terlewatkan maka pengurus perseroan sudah tidak dapat mengajukan kepada menteri agar menyetujui perubahan anggaran dasar. Berdasarkan pemaparan tersebut maka bagaimanakah akibat hukum/sanksi apabila Perseroan Terbatas belum mendapatkan persetujuan akta perubahan anggaran dasar oleh Kemenkumham tetapi tetap menjalankan aktivitas Perseroan Terbatas. Apabila dikaitkan dengan Pasal 21 ayat (1) UUPT yang mengahruskan mendapatkan persertujuan Kemenkumham, tentu menimbulkan kebingungan karena tidak ada pengaturan atau adanya kekosongan norma mengenai sanksi dari permasalahan yang dipaparkan. 
Pemaparan dari masalah itu memberi inspirasi serta ide-ide untuk menjadikan permasalahan ini sebagai sebuah jurnal yang berjudul Pengaturan Sanksi Tentang Perubahan Anggaran Dasar Perseroan Terbatas Tanpa Persetujuan Kemenkumham. Adapun permasalahan-permasalahan terdapat pada penulisan yaitu : Bagaimana sanksi terhadap PT dalam menggunakan Akta Perubahan Anggaran Dasar yang baru namun belum disetujui oleh Kemenkumham? Bagaimana kedudukan Akta Perubahan Anggaran Dasar PT yang belum mendapatkan persetujuan Kemenkumham?

Penelitian ini memiliki sebuah tujuan dan terbagi atas tujuan yang memiliki sifat umum dan khusus. Tujuan umum penelitian ini dilakukan adalah untuk mengetahui seberapa penting persetujuan Kemenkumham terhadap Perubahan Anggaran Dasar PT bagi PT. Tujuan khusus dalam penelitian ini yaitu menganalisa bagaimana sanksi pada PT yang menggunakan Akta Perubahan Anggaran Dasar yang baru namun belum disahkan oleh Kemenkumham serta mengkaji kedudukan Akta Perubahan Anggaran Dasar PT yang belum mendapatkan persetujuan Kemenkumham. Kajian teoritis terdapat di dalam penulisan jurnal ini, semoga memberikan hal positif kepada pembaca sebagai acuan pada program kenotariatan dalam hal pengajuan Akta perubahan anggaran dasar PT kepada Kemenkumham.

Manfaat yang diharapkan dapat tercapai dari adanya penelitian jurnal yaitu pada bidang pendidikan dan kehidupan di masyarakat tulisan ini diharapkan dapat memberi manfaat sebagai tambahan wawasan untuk pembelajaran khususnya di bidang PT. Untuk masyarakat luas penulisan jurnal ini diharapkan dapat memberi pembelajaran mengenai hal-hal yang dilakukan dalam pendirian PT khususnya dalam langkah-langkah pengubahan anggaran dasar setelah didirikanya PT.

Penulisan ini dibuat menggunakan pemikiran-pemikiran yang baru dan orisinal dan guna untuk menghindari adanya unsur-unsur plagiat dalam penulisan jurnal-jurnal di kemudian hari, walaupun ada kemungkinan kemiripan judul penelitian atau maksud dengan penulisan yang lain berikut beberapa judul jurnal beserta penulisnya antara lain :

1. Jurnal yang ditulis oleh Nur Andayani, diterbitkan oleh Jurnal Hukum Fakultas Hukum Universitas Brawijaya, Tahun 2016. Judul "Implikasi Yuridis Perubahan Anggaran Dasar Perseroan Terbatas Yang Dilakukan Notaris Tanpa Ada Keputusan Rapat Umum Pemegang Saham (RUPS)." Permasalahan yang dikaji yaitu bagaimanakah kekuatan hukum dari perubahan Anggaran Dasar Perseroan Terbatas yang dibuat oleh pejabat notaris tidak melalui RUPS serta bagaimana kekuatan hukum dari perbuatan pengurus PT jika terdapat sebuah kekeliruan anggaran dasar yang terjadi pada jabatan kepengurusan yang berbeda.

2. Jurnal yang ditulis oleh Yohana Feryna, diterbitkan oleh Jurnal Cakrawala Hukum,Volume.7, Nomor.2 Fakultas Hukum Universitas Merdeka 
Malang, Tahun 2016. Judul Makna Kesepakatan Para Pihak Terhadap Perubahan Modal Dasar Perseroan Terbatas .Permasalahan yang dikaji yaitu Apa makna kesepakatan para pihak pada Pasal 1 ayat (3) Peraturan Pemerintah Republik Indonesia Nomor 29 Tahun 2016 tentang Perubahan Modal Dasar Perseroan Terbatas serta apakah akibat hukum dari perubahan besaran modal dasar PT menjadi kesepakatan para pendiri PT dan bagaimana formulasi terhadap Undang-Undang Perseroan Terbatas sehingga para pembuat perjanjian memperoleh kepastian hukum.

Menurut perbandingan dengan jurnal terdahulu dengan tulisan ini tidak ada maksud serta niat untuk menjiplak ataupun mengcopy tulisan-tulisan yang sudah ada sebelumnya. Tulisan ini memiliki judul Pengaturan Sanksi Tentang Perubahan Anggaran Dasar Perseroan Terbatas Tanpa Persetujuan Kemenkumham .Permasalahan yang dibahas yaitu mengenai sanksi terhadap Perseroan Terbatas yang menggunakan Akta Perubahan Anggaran Dasar yang baru namun belum disetujui oleh Kemenkumham dan kedudukan Akta Perubahan Anggaran Dasar PT dan belum mendapatkan persetujuan Kemenkumham.

\section{Metode Penelitian}

Metode yang terdapat pada kajian ilmu hukum berawal dari sifat/karakter ilmu hukum itu. Ilmu hukum itu memiliki sifat/karakter khusus yaitu memiliki sifat normatif, perspektif dan praktis. ${ }^{6}$

Pada penelitian jurnal yang dikerjakan, digunakan jenis penelitian hukum yang bersifat normatif.Karakteristik dari dilakukanya penelitian ini yaitu memberikan landasan teoritis terhadap berlakunya norma hukum baik deskripsi ataupun preskripsi oleh hukum normatif. ${ }^{7}$ Awal mula masalah yang timbul pada penelitian ini yakni terlihat pada kekosongan norma dalam UUPT. Hal yang dimaksud sebagai kekosongan norma dalam UUPT merujuk pada belum diaturnya sanksi apabila Perseroan Terbatas belum mendapatkan persetujuan dari Kemenkumham mengenai akta perubahan anggaran dasar namun tetap menjalankan kegiatan perusahaanya dengan menggunakan akta perubahan anggaran dasar yang belum mendapatkan persetujuan tersebut. UUPT disini cukup mengatur mengenai wajibnya perubahan anggaran dasar PT yang memiliki persetujuan dari Kemenkumham yaitu dalam Pasal 21 ayat (1) UUPT. Pendekatan yang digunakan yaitu pendekatan perundang-undangan dan pendekatan konseptual. Permasalahan yang terjadi tersebut dikaji dengan menganalisa aturan-aturan hukum mana saja yang berhubungan dalam permasalahan yang dikaji. Hal tersebut dimaksud sebagai pendekatan perundang-undangan. Pendekatan yang digunakan dalam mengidentifikasi dan

\footnotetext{
${ }^{6}$ Laurensius Aliman S.(2018).Peranan Metodologi Penelitian Hukum di Dalam Perkembangan Ilmu Hukum di Indonesia.Soematra Law Review.h.116

7 I Made Pasek Diantha.(2016).Metodologi Penelitian Hukum Normatif,Jakarta:Kencana.h88
} 
menetapkan konsep dalam hukum, memahami konsep, serta memberikan suatu definisi dari penelitian yang dibahas dimaksud sebagai pendekatan konseptual .8 Penelitian ini memiliki sumber data yang berasal dari data sekunder yang terdiri dari :

a. Bahan hukum memiliki sifat yang mengikat atau pada umumnya dikenal sebagai bahan hukum primer ${ }^{9}$, contoh bahan hukum yang dimaksudkan itu diantaranya :

1. KUHPerdata

2. KUHPidana

3. UUPT

b. Bahan hukum yang memiliki kaitan dengan sumber bahan hukum primer dan biasanya menjelaskan lebih detail tentang bahan hukum primer sering disebut sebagai bahan hukum sekunder yang dimaksudkan itu diantaranya :

1. Buku

2. Jurnal-jurnal berkaitan dengan ilmu hukum

3. Doktrin / pendapat para ahli.

c. Bahan hukum yang memiliki fungsi sebagai penambah informasi data terhadap sumber bahan hukum yang berisifat primer maupun sekunder yang dimaksudkan tersebut seperti :

1. Artikel

2. KBBI

3. Koran

\section{Hasil dan Pembahasan}

\subsection{Sanksi Terhadap Perseroan Terbatas yang Mengggunakan Akta Perubahan Anggaran Dasar yang Baru Namun Belum Disetujui oleh Kemenkumham}

Pasal 21 ayat (2) UUPT mengatur tentang Perubahan Anggaran Dasar Perseroan Terbatas. UUPT menyebutkan bahwa pengajuan perubahan tersebut diharuskan disetujui dahulu oleh Kemenkumham. Hal-hal yang dimaksud di dalamnya sebagai berikut :

a. nama serta lokasi berdirinya PT

b. bidang usaha yang digeluti oleh PT,

c. tenggang waktu berdirinya PT,

d. jumlah modal yang dimiliki oleh PT,

e. pengaturan modal disetor/ ditempatkan,

f. status kedudukan dari PT bersifat tertutup hingga menjadi PT yang terbuka.

\footnotetext{
8 Johnny Ibrahim.(2018).Teori dan Metodologi Penelitian Hukum Normatif,Jakarta:Bayumedia.h.310

9 Soerjono Soekanto dan Sri Mamujdi (2011), Penlitian Hukum Normatif Suatu Tujuan Singkat, Jakarta:Rajagrafindo,h.13 .
} 
Selain ketentuan-ketentuang yang ada pada Pasal 21 ayat (2) UUPT hanya memberi tahu Kemenkumham.

PT yang sedang dalam pengajuan perubahan anggaran dasar yang baru lalu belum mendapatkan persetujuan Kemenkumham dan Perseroan Terbatas tetap menjalankan kegiatan perusahaannya dengan menggunakan akta perubahan anggaran dasar yang baru serta menggunakan nama perseroan, tempat kedudukan, dan tujuan kegiatan perseroan yang baru. Tindakan ini merupakan sebuah pelanggaran hukum karena pada Pasal 21 ayat (1) UUPT diatur keharusan memperoleh persetujuan Kemenkumham, namun di dalam UUPT belum mengatur sanksi mengenai tindakan pelanggaran yang disebabkan oleh PT.

Pada Kitab Undang-Undang Hukum Perdata (Selanjutnya disingkat KUHPerdata) pelanggaran ini dapat tergolong sebagai perbuatan melawan hukum sebagaimana tercantum pada Pasal 1365 KUHPerdata yang berbunyi: Tiap perbuatan yang melanggar hukum dan membawa kerugian terhadap orang lain, mewajibkan orang yang menimbulkan kerugian tersebut karena kesalahanya untuk mengganti kerugian tersebut. Perbuatan melawan hukum(Selanjutnya disingkat PMH) menurut pendapat Munir Fuady diartikan sebagai gabungan prinsip hukum yang berguna sebagai alat kontrol tindakan berbahaya, dan memberikan pertanggung jawaban atas kerugian yang ditimbulkan kepada korban.

Perbuatan melawan hukum digolongkan ke dalam tindakan maupun perbuatan sebagai berikut yakni :

1. perbuatan yang tidak mematuhi Undang-undang disebabkan oleh kesengajaan

2. PMH tidak disebabkan oleh adanya kelalaian / kesengajaan

3. PMH yang disebabkan oleh kelalaian. ${ }^{10}$

Unsur-unsur sebuah tindakan yang digolongkan sebagai tindakan yang melawan hukum diantaranya :

1. terdapat sebuah tindakan

2. tindakan itu melanggar undang-undang

3. pelaku membuat kesalahan

4. timbul kerugian dari pihak lain

5. timbul hubungan dari perbuatan dan kerugian

Perbuatan oleh Perseroan Terbatas tersebut sudah masuk ke dalam kategori tindak PMH. PMH secara sempit adalah tindakan yang tidak sesuai dengan

10 Evalina Yessica. (2014).Karakteristik dan Kaitan antara Perbuatan Melawan Hukum dan Wanprestasi.Journal Repertorium Sebelas Maret University.h.51 . 
Perundang-undangan. ${ }^{11}$ Tindakan tersebut akan dapat merugikan pihak lainya kedepannya karena adanya ketidakjujuran atau ketidakterbukaan mengenai informasi Perseroan Terbatas dan memungkinkan terjadinya wanprestasi. Terdapat kesengajaan yang dilakukan oleh PT dengan kondisi yang jelas-jelas melanggar ketentuan UUPT pada pasal 21 ayat (2) UUPT yang mewajibkan PT harus mendapat persetujuan Kemenkumham dalam pengajuan perubahan anggaran dasar tetapi PT tidak mematuhi ketentuan yang sudah ditetapkan dalam 21 ayat 2 UUPT. PT dapat dikenakan sanksi apabila dalam hal ini melakukan penipuan/wanprestasi, merugikan para pihak dan pihak mengalami kerugian dapat melaporkan hal itu maka sanksinya perseroan terbatas harus mengganti seluruh jumlah ganti rugi yang dirasakan oleh mitra bisnis PT.

Di dalam Kitab Undang-Undang Hukum Pidana (Selanjutnya disingkat KUHPidana) perbuatan yang dilakukan oleh Perseroan Terbatas ini dapat dikategorikan sebagai penipuan. Dalam pasal 378 KUHPidana, penipuan merupakan "Barang siapa untuk menguntungkan diri sendiri atau orang lain dengan cara melawan hukum menggunakan nama palsu atau martabat palsu dengan tipu muslihat atau dengan rangkaian kebohongan menggerakkan orang lain untuk menyerahkan suatu benda kepadanya atau supaya memberi hutang maupun menghapuskan piutang, diancam hukuman pidana penjara paling lama empat tahun".12 Tindakan penipuan telah memenuhi unsur perbuatan PMH yaitu adanya penggunaan nama palsu, rangkain kebohongan, serta dapat membuat orang lain dirugikan. Tindakan Perseroan Terbatas sudah sangat jelas telah memenuhi unsur-unsur dari tindakan penipuan tersebut dan dapat dimintai pertanggung jawaban hingga dikenai sanksi pidana selama 4 tahun penjara.

\subsection{Kedudukan Akta Perubahan Anggaran Dasar Perseroan Terbatas yang belum mendapatkan persetujuan Kemenkumham}

Akta Perubahan Anggaran Dasar Perseroan Terbatas terbagi atas akta perubahan anggaran perseroan dasar yang wajib disetujui oleh Kemenkumham diatur dalam Pasal 21 ayat (1) UUPT dan Akta Perubahan Anggaran Dasar yang hanya diberitahukan kepada menteri diatur dalam Pasal 21 ayat 3 UUPT. Jika Perubahan Anggaran Dasar PT telah disetujui oleh Kemenkumham maka untuk secara lebih sah nya akan diumumkan pada Tambahan Berita Negara Republik Indonesia(selanjutnya disingkat TBN RI).

TBN RI diatur dalam pasal 30 ayat (1) UUPT yang berbunyi : Menteri mengumumkan dalam Tambahan Berita Negara Republik Indonesia

11 RB Budi Prastowo.(2006).Delik Formil/Materiil dan Sifat Melawan Hukum Formil/Materiil.Jurnal Hukum Pro Justisia Volume 24 No.3.h.215 .

12 D Sudarsono.(2016) Penipuan yang Mengatasnamakan Arisan Dihubungkan dengan Pasal 378 KUHP.Institutional Repositories E Scientifics Journal Universitas Pasundan.h4 . 

a. akta pendirian Perseroan beserta keputusan menteri sebagaimana dimaksud dalam Pasal 7 ayat (4);
b. akta perubahan anggaran dasar Perseroan beserta keputusan menteri sebagaimana dimaksud dalam Pasal 21 ayat (1);
c. akta perubahan anggaran dasar yang telah diterima pemberitahuanya oleh Menteri.

Berkaitan dalam hal pengumuman pada TBN RI dilihat dari sisi hukum, pengumuman tersebut mengaplikasikan asas publisitas kepada pihak masyarakat luas dan pihak ketiga. Dengan kata lain TBN RI ini menentukan keabsahaan hubungan hukum Perseroan kepada pihak ketiga walaupun Akta Perubahan Anggaran Dasar tersebut telah disetujui oleh Menteri. Jika Akta Perubahan Anggaran Dasar tersebut belum memperoleh persetujuan Kemenkumham dan belum diumumkan dalam TBN Republik Indonesia maka kedudukan Akta Perubahan Anggaran Dasar tidak sah dan tidak dapat mengikat Perseroan Terbatas dengan pihak-pihak lain. ${ }^{13}$ Akta Perubahan Anggaran Dasar yang lama yang kembali berlaku dan PT tidak berhak untuk menggunakan Akta Perubahan Anggaran Dasar yang baru.

\section{Kesimpulan}

Sanksi dari pelanggaran yang dilakukan oleh PT belum diatur dalam UUPT. Dalam hal ini pelanggaran yang dilakukan yaitu penggunaan perubahan anggaran dasar yang belum mendapatkan persetujuan oleh Kemenkumham tetapi tetap menggunakan perubahan anggaran dasar yang baru sehingga melanggar ketentuan pada Pasal 21 ayat (1) UUPT. Sanksi dari perbuatan Perseroan Terbatas tersebut dapat dilihat pada KUHPerdata.Dalam KUHPerdata, perbuatan PT tersebut termasuk/dikategorikan sebagai PMH. PMH pada tercantum pasal 1365 KUHPerdata. PMH diartikan sebagai tindakan yang melanggar undang-undang dan pihak-pihak dirugikan atas tindakannya dan harus mengganti atas kerugian itu. Perbuatan PT telah memenuhi ketentuan sebagai tindakan melawan hukum yaitu merupakan tindakan yang melanggar hukum, baik itu dengan kesengajaan. PT dapat dikenakan sanksi apabila pihak lain tersebut dirugikan oleh pihak Perseroan Terbatas. Sanksi itu berupa ganti rugi sesuai atas dengan nilai kerugian yang ditimbulkan. Dalam KUHPidana pelanggaran yang dilakukan oleh PT tersebut dikategorikan sebagai perbuatan penipuan yang diatur dalam pasal 378 KUHPidana, penipuan yang dilakukan yaitu menggunakan nama dan tujuan PT yang belum sah maka dapat dikategorikan sebagai nama palsu dan dapat dikenakan sanksi pidana selama 4 tahun penjara.

Kedudukan Akta Perubahan Anggaran Dasar tersebut belum memperoleh persetujuan Kemenkumham dan belum diumumkan dalam TBN Republik

13 M.Yahya Harahap,(2009), Hukum Perseroan Terbatas, Jakarta: Sinar Grafika, h.230 . 
Indonesia itu tidak sah dan tidak dapat mengikat Perseroan Terbatas dengan pihak-pihak lain. ${ }^{14}$ Akta Perubahan Anggaran Dasar yang lama yang kembali berlaku dan PT tersebut tidak berhak untuk menggunakan Akta Perubahan Anggaran Dasar yang baru.

\section{Daftar Pustaka}

\section{$\underline{\text { Buku }}$}

Asikin,H.Z. (2016). Pengantar Hukum Perusahaan, Jakarta:Kencana .

Diantha, I.M.P.(2016).Metodologi Penelitian Hukum Normatif,Jakarta:Kencana .

Harahap,M.Y.(2009).Hukum Perseroan Terbatas, Jakarta: Sinar Grafika .

Ibrahim,Johnny.(2018).Teori dan Metodologi Penelitian Hukum Normatif, Jakarta:Bayumedia .

Purba,O. (2011). Petunjuk Praktis Bagi Rups Komisaris dan Direksi Perseroan Terbatas agar Terhindar Dari Jerat Hukum, Jakarta: Raih Asa Sukses .

Soekanto, S \& Mamujdi, S.(2011). Penlitian Hukum Normatif Suatu Tujuan Singkat, Jakarta:Rajagrafindo .

\section{Jurnal Ilmiah}

Aliman.L.S.(2018).Peranan Metodologi Penelitian Hukum di Dalam Perkembangan Ilmu Hukum di Indonesia.Soematra Law Review

Khairandy.R. (2013).Karakter Hukum Perusahaan Perseroan Dan Status Hukum Kekayaan Yang Dimilikinya. Jurnal Hukum Ius Quia Iustum

Pahlefi. (2016). Eksitensi RUPS sebagai Organ Perseroan Terkait Dengan Pasal 91 Undang-Undang Perseroan Terbatas.Jurnal Ilmu Hukum Unja, Volume 7 No. 2

Prastowo.RB.B.(2006).Delik Formil/Materiil dan Sifat Melawan Hukum Formil/Materiil.Jurnal Hukum Pro Justisia Volume 24 No.3

Sudarsono.D. (2016) Penipuan yang Mengatasnamakan Arisan Dihubungkan dengan Pasal 378 KUHP.Institutional Repositories \& Scientifics Journal

14 M.Yahya Harahap,(2009), Hukum Perseroan Terbatas, Jakarta: Sinar Grafika, h.230 . 
Wihanjaya.A. (2016).Analisis Terhadap Kewajiban Direksi Perseroan Dalam Menyelenggarakan Rapat Umum Pemegang Saham. Jurnal Online Mahasiswa Bidang Hukum

Yessica.E. (2014).Karakteristik dan Kaitan antara Perbuatan Melawan Hukum dan Wanprestasi.Journal Repertorium Sebelas Maret University

\section{Peraturan Perundang-undangan}

Kitab Undang-Undang Hukum Perdata

Kitab Undang-Undang Hukum Pidana

Undang-Undang Republik Indonesia Nomor 40 Tahun 2017 Tentang Perseroan Terbatas 